\title{
Communication
}

\author{
[Comunicação]
}

\section{Assessment of Newcastle and infectious bronchitis pathogens, and Salmonella spp. in wild birds captured near poultry facilities}

\author{
[Pesquisa de Salmonella spp., de doença de Newcastle e de bronquite infecciosa em aves \\ silvestres capturadas próximo a instalações avícolas]
}

\section{E. Sousa, K. Werther, A. Berchieri Júnior}

Faculdade de Ciências Agrárias e Veterinárias - UNESP

Via de Acesso Prof. Paulo Donato Castellane, s/n 14884-900 - Jaboticabal, SP

Preservation of high production levels in the Brazilian poultry industry requires some biosafety measures. Among these, poultry facilities must be built distant from cities and in places without intense human traffic. Thus, poultry facilities are built next to forests, which work like physical barriers. However, forests are inhabited by wild birds that may serve as carriers of avian pathogens (Hubalek, 2004), such as Newcastle disease virus (NDV), infectious bronchitis virus (IBV), and Salmonella spp. Infection of poultry with these pathogens may lead to economical losses.

In Brazil, NDV has not been isolated from freeliving birds but from captive birds in Rio de Janeiro (Couceiro et al., 1990), greater flamingo (Phoenicopterus ruber) (Doretto Jr. et al., 1999a), and ostrich (Struthio camelus) (Doretto Jr. et al., 1999b). As for IBV, it has been isolated in Brazil from exotic birds including domestic guinea fowl (Miyaji, 1996) and Japanese quail (Di Fabio et al., 2000). Numerous serotypes of Salmonella spp. have been isolated from many species of wild birds in the world. In Brazil, has been isolated $S$. Typhimurium from great egret (Ardea alba) (Freitas et al., 1977) and S. Typhimurium serotype $S$. enterica subsp. enterica 4 and 12 and $S$. enterica subsp. enterica 4 and 12 from rock pigeons (Marciano, 2004).

Considering viral (NDV and IBV) and bacterial (salmonellosis) diseases, which can affect avians and represent a risk for public health, the present

Recebido em 9 de dezembro de 2009

Aceito em 19 de fevereiro de 2010

E-mail: werther@fcav.unesp.br work aimed to detect the presence of antibodies against Salmonella Pullorum, NDV, and IBV, and to identify the presence of Salmonella spp. in wild birds living next to poultry facilities, since they could represent a source of infection for the poultry industry.

In this study, 48 wild birds were captured next to an avian facility in the north of São Paulo State. All procedures for capture and sampling of biologic material were authorized by the IBAMA-SP (Process number 02027.000775/2005-25; license number $500 / 2005)$.

To perform the hemagglutination inhibition (HI) assay for the detection of antibodies against $\mathrm{NDV}$, the four unities of hemagglutination activity (4UHA) of the LaSota strains of NDV was determined. Briefly, sera samples from the wild birds were heat inactivated at $56^{\circ} \mathrm{C}$, for $30 \mathrm{~min}$, and again submitted to $56^{\circ} \mathrm{C}$ for $10 \mathrm{~min}$ to remove any possible nonspecific $\mathrm{HA}$ inhibitor. Twofold serial dilutions of sera samples from at $1: 20$ up to $1: 2048$ were done in a $25 \mu \mathrm{L}$ in a microtiter plate. Dilutions were made in phosphate buffered saline (PBS 0.01M, pH 7.2). After incubation at room temperature (RT) for $15 \mathrm{~min}$, the serum-virus mixtures were added an equal volume of $25 \mu \mathrm{L}$ of chicken erythrocytes in PBS, as a test indicator. Reading was performed after 30min incubation at RT. The HI end point was determined as the last dilution with complete inhibition of HA activity. According to the Office of International Epizooties standard 
procedures, samples presenting titers equal to or higher than 16 are considered positive for a 4UHA antigen concentration.

The technique of virus neutralization was used to determine titers of antibodies to IBV. Briefly, serum samples $(50 \mu \mathrm{L}$ of serial two-fold dilutions) with $100 \mu \mathrm{L}$ of Eagle minimal essential medium with L-Glutamine, without sodium bicarbonate and supplemented with $1.5 \%$ dextrose and gentamycin $(10 \mu \mathrm{g} / \mathrm{mL})$, were added to each well, beginning from the second column. The first column was added with cell control. Viral suspension $(50 \mu \mathrm{L})$ was added to each well from the third column. After incubation of the plates at $37^{\circ} \mathrm{C}$ for $30 \mathrm{~min}$, kidney cell suspensions from specific-pathogen-free (SPF) one-day-old chicks were added as indicator cells $(800.000$ cells $/ \mathrm{mL}$ ). Cell control, virus control, positive control, and negative control serum samples were included in each neutralization test, and incubated at $37^{\circ} \mathrm{C}$ in $\mathrm{CO}_{2}$ for $72 \mathrm{~h}$. All plates were read within $72 \mathrm{~h}$ for cytopathic effect using an inverted microscope.

Rapid Plate Agglutination (RPA) assay was used to detect antibodies to Salmonella. For the serologic test, one drop of antigen (Salmonella Pullorum) and one drop of serum sample were mixed on a glass plate and incubated at RT. A positive reaction with clearly distinguishable agglutination was considered within two minutes after mixture of serum and antigen.

Salmonella spp. was identified by means of culture, biochemical, and serotyping characteristics by standard procedures. Fragments of liver, spleen, and ovaries/testicles (as a pool) and intestinal content were placed in buffered peptone water (Oxoid MO509 Basingstoke, England) pre-enrichment broth at $37^{\circ} \mathrm{C}$ for $24 \mathrm{~h}$. After incubation, $0.1 \mathrm{~mL}$ of broth clutter was placed in tubes containing $10 \mathrm{~mL}$ of Rappaport (RP) and $1 \mathrm{~mL}$ of tissue solution and intestinal content was transferred to tubes containing $10 \mathrm{~mL}$ of Selenite (SN) and incubated at $37^{\circ} \mathrm{C}$ for $24 \mathrm{~h}$. After selective enrichment, a loopful of each broth was streaked into a brilliant green agar plate and a MacConkey (Oxoid CM 263 and CM 115) agar plate. Both plates were incubated at $37^{\circ} \mathrm{C}$ for $24 \mathrm{~h}$. Three of the Salmonella-suspected colonies were selected from these plates and inoculated in Triple Sugar Iron agar and in Lisina Iron agar (Oxoid CM 277 and CM 381). Positive colonies from tubes were subjected to RPA. Next, all material was sent to Instituto Adolfo Lutz, São Paulo, Brazil, for serotyping.

A total of 48 wild birds were captured including 13 southern lapwings (Vanellus chilensis), nine burrowing owls (Speotyto cunicularia), eight chalk-browed mockingbirds (Mimus saturninus), five red-legged seriemas (Cariama cristata), two guira cuckoos (Guira guira), two ruddy grounddove (Columbina talpacoti), two barn owls (Tyto alba), one great kiskadee (Pitangus sulphuratus), one campo flicker (Colaptes campestris), one eared dove (Zenaida auriculata), one peachfronted parakeet (Aratinga áurea), one buffnecked ibis (Theristicus caudatus), one roadside hawk (Buteo magnirostris), and one swallowtailed hummingbird (Eupetomena macroura).

Among the captured wild birds, one blood sample was excluded because it hemolyzed, thus 47 samples were used for investigation of antibodies anti-IBV, NDV, and Salmonella Pullorum by VN, HI, and RPA assays, respectively.

All sera were negative for antibodies to NDV by HI. The absence of NDV antibodies may be explained by kinetics persistence of antibodies in the blood stream (from 15 up to 101 days postinfection), and such results agree with similar negative findings for rock pigeon experimental infection (Carrasco, 2005). It is also possible that the virus was incapable of stimulating the immunological system of those birds, or perhaps the virus was not present among the wild birds studied. Conversely, Demétrio (2002) reported the detection of NDV in non-vaccinated wild birds by PCR, which suggests a role for wild birds in the transmission of NDV. The presence of antibodies to NDV in non-vaccinated domestic birds supports this idea (Oliveira Jr. et al., 2003), which indicates that chickens could have been exposed to NDV carried by wild birds.

All sera were negative for antibodies to IBV. The absence of IBV antibodies in all examined sera may be explained by lack of knowledge about kinetics of antibodies in different wild bird species. In addition, domestic chickens are known to carry a maximum antibody level at around seven days post-infection, and antibodies may persist from 20 to 90 days post-infection (Di 
Fabio and Rossini, 2000). In the present study, the studied birds might have not developed detectable antibodies in the blood sampled, or maybe they had not yet developed a humoral immune response. Although no antibodies to IBV were detected in the present study, some authors reported the isolation of IBV from domestic guineafowl (Miyaji, 1996) and Japanese quails (Di Fabio et al., 2000). The presence of IBV in exotic and wild birds may be affected by interaction among species or by their close relation to commercial birds flocks. The present study analyzed the presence of chicken antibodies to IBV in wild birds. The fact that the presence of coronavirus was not detected in the wild birds here collected does not rule out the possibility that these birds serve as biological carriers of other types of coronavirus that are species-specific. Here, the results were limited to coronavirus specific for chicken infection. Further studies are necessary to investigate the presence of coronaviruses that are specific to wild birds and their potential for transmission to chickens as demonstrated in China (Qian et al., 2006). It the Qian et al. study, pigeon coronavirus inoculated in specific-pathogen-free (SPF) chickens caused pancreatitis in those birds.

One buff-necked ibis (Theristicus caudatus) out of the 48 sera collected from wild birds was positive for antibodies to Salmonella Pullorum detected by the RPA test. Salmonella Muenchen was isolated from a cloacal swab sample (collected during the necropsy) from this bird. The fact that this buff-necked ibis was serapositive at RPA but culture findings revealed another serotype did not come as a surprise. It is possible that the RPA may represent either false positive results or cross-reactivity with other Salmonella spp., mainly those belonging to the D group, since such serotypes have similar antigenic composition. No Salmonella was isolated from a pool of organ (liver, spleen, and ovaries/testicles) tissues or from the intestinal content samples from this buff-necked ibis (Theristicus caudatus), although two portions of the intestine were examined. The Salmonella species isolated from cloacal swabs might be restricted to the last portion of the intestinal tract. In the present study, $S$. Muenchen was isolated from a pool of organs (liver, spleen, and ovaries/testicles), whereas $S$. Saintpaul was isolated from the intestinal content of a redlegged seriema (Cariama cristata) and $S$. Enteritidis (SE) was isolated from the intestinal content of an eared dove (Zenaida auriculata). Serology presented negative results for both species, which may be explained by the fact that birds with early infection may not have detectable systemic antibodies, resulting in false negative results.

Among pigeons, $S$. Typhimurium is the most common serotype isolated (Marciano, 2004). However, in this study, $S$. Enteritidis was isolated from pigeons instead. Those birds may have possibly acquired infection by feeding on contaminated chicken food. Additionally, contamination of the environment by SE or infected chickens may be involved in the transmission of the agent, since SE-positive chickens release SE through faeces, thereby contaminating the environment.

$S$. Muenchen was isolated from two out of three (66.6\%) Salmonella spp. positive bird samples, although isolation of $S$. Muenchen has been reported as being rare (Hofer et al., 1997).

$S$. Saintpaul was isolated from buff-necked ibis whereas $S$. Saintpaul and $S$. Muenchen were isolated from red-legged seriema and buffnecked ibis, which may be explained by ingestion of small vertebrates, which are part of their feeding habits. However, these serotypes had already been isolated from snakes and amphibians (Bufo marinus), which are prey for free-living birds. Reptiles are generally considered healthy carriers of Salmonella spp.

The results found in the current study provided further evidence that the wild birds may represent a risk for both humans and the poultry industry since their faeces can serve as a source for dissemination of Salmonella spp., because the wild birds live, feed, and defecate very near to the aviculture installations. Further studies are necessary to assess circulating strains and establish the losses due to infection caused by this agent.

Keywords: wild bird, chicken, Newcastle disease virus, infectious bronchitis virus, Salmonella spp. 


\section{RESUMO}

Aves de vida livre podem ser carreadoras e disseminadoras de agentes patogênicos e representarem um risco para galinhas de produção. $O$ objetivo deste trabalho foi verificar em aves de vida livre a presença de anticorpo contra: Salmonella Pullorum (SP), vírus da doença de Newcastle (VDN) e vírus da bronquite infecciosa (VBI), bem como a presença de Salmonella spp. De 48 aves de vida livre capturadas nas imediações de uma granja avícola, no norte do Estado de São Paulo, em 2005 e 2006, foram colhidos soros para realização de testes de soroaglutinação rápida em placa (SAR) para SP, inibição de hemaglutinação (HI) para o VDN e soroneutralização (SN) para VBI. Foram colhidos fragmentos de fígado, baço e ovários/testículos, todos cultivados juntos como um pool e conteúdo intestinal separado, para cultura de Salmonella spp. Todas as amostras foram negativas para a doença de Newcastle e bronquite infecciosa. Quanto à Salmonella Pullorum, pela técnica de SAR, a amostra de Theristicus caudatus foi positiva. No exame bacteriológico, foi isolado o agente em três aves: Theristicus caudatus (Salmonella Muenchen), Zenaida auriculata (Salmonella Enteritidis) e em Cariama cristata tanto Salmonella Muenchen como Salmonella Saintpaul.

Palavras-chave: ave silvestre, galinha, vírus da doença de Newcastle, vírus da bronquite infecciosa, Salmonella spp.

\section{ACKNOWLEDGEMENTS}

The authors acknowledge the Ornitophatology Laboratory at the UNESP - Jaboticabal, and Instituto Adolfo Lutz - São Paulo, for technical assistance.

\section{REFERENCES}

CARRASCO, A.O.T. Infecção experimental de pombos com estirpes do vírus da doença de Newcastle de baixa e alta patogenicidade. 2005. 71f. Dissertação (Mestrado) - Faculdade de ciências Agrárias e Veterinárias, Universidade Estadual Paulista, Jaboticabal, SP.

COUCEIRO, J.N.; MACHADO, R.D.; COUCEIRO, E.S. et al. Prevalência do vírus da doença de Newcastle em uma comunidade de aves ornamentais. Pesq. Vet. Bras., v.10, p.3133, 1990 .

DEMÉTRIO, C. Levantamento sorológico e pesquisa do vírus da doença de Newcastle em irerês migratórios, Dendrocygna viduata (Anseriformes: Anatidae), na cidade de São Paulo, Brasil. 2002. 62f. Dissertação (Mestrado) - Universidade de São Paulo, São Paulo.

DI FABIO, J.; ROSSINI, L.I. Bronquite Infecciosa das Galinhas. In: BERCHIERI JUNIOR, A.; MACARI, M. (Ed.). Doenças das aves. Campinas: FACTA, 2000. p.293-300.

DI FABIO, J.; ROSSINI, L.I.; ORBELL, S.J. et al. Characterization of infectious bronquites viruses isolated from outbreaks of disease in commercial flocks in Brasil. Avian Dis., v.44, p.582-589, 2000.

DORETTO Jr., L.; ORSI, M.A.; GALLETTI, M.C.M. et al. Isolamento do vírus da DN em flamingo (Phoenicopterus ruber) importado pelo Brasil. In: CONFERÊNCIA APINCO DE CIÊNCIA E TECNOLOGIA AVÍCOLAS, 1999, Campinas. Anais... Campinas: [s.n.] 1999a. p.86. (Resumo).

DORETTO Jr., L.; ORSI, M.A.; GALLETTI, M.C.M. et al. Isolamento do vírus da DN em 2 lotes de pintos de avestruzes (Struthio camelus) importados pelo Brasil. In: CONFERÊNCIA APINCO DE CIÊNCIA E TECNOLOGIA AVÍCOLAS, 1999, Campinas. Anais... Campinas: [s.n.] 1999b. p.88. (Resumo).

FREITAS, M.A.Q.; SANTOS, J.A.; PIRES, A.R. et al. Infecção por Salmonella Typhimurium de origem hídrica em garça gigante (Casmerodius albus egretta) em sua vida livre no Estado do Rio de Janeiro. Rev. Soc. Br. Med. Trop., v.11, p.161-166, 1977.

HOFER, E.; SILVA FILHO, S.J.; REIS, E.M.F. Prevalência de sorovares de Salmonella isolados de aves no Brasil. Pesq. Vet. Bras., v.17, p.55$62,1997$.

HUBÁLEK, Z. An annotated checklist of pathogenic microorganisms associated with migratory birds. J. Wildl. Dis., v.40, p.639-659, 2004.

MARCIANO, J.A. Pesquisa de Salmonella spp., Cryptococcus neoformans $e$ anticorpos anti- 
Toxoplasma gondii em pombos urbanos (Columba livia) no município de Jaboticabal-SP. 2004. 65f. Dissertação (Mestrado) - Faculdade de ciências Agrárias e Veterinárias, Universidade Estadual Paulista, Jaboticabal, SP.

MIYAJI, C.I. Vírus da bronquite infecciosa das galinhas: estudo comparativo de amostras isoladas de rim de galinhas d' angola e de frangos de corte. 1996. 72f. Dissertação (Mestrado) - Faculdade de Medicina Veterinária Zootecnia da Universidade de São Paulo, São Paulo.
OLIVEIRA Jr., J.G.; PORTZ, C.; LOUREIRO, B.O. et al. Vírus da doença de Newcastle em aves não vacinadas no Estado do Rio de Janeiro. Cienc. Rural, v.33, p.381-383, 2003.

QIAN, D.H.; ZHU, G.J.; WU, L.Z. et al. Isolation and characterization of a coronavirus from pigeons with pancreatitis. Am. J. Vet. Res., v.67, p.1575-1579, 2006. 